Check for updates

Cite this: RSC Adv., 2018, 8, 38416

\section{Preparation, characterization and reusability efficacy of amine-functionalized graphene oxide- polyphenol oxidase complex for removal of phenol from aqueous phase}

\begin{abstract}
Pravin M. D., Chris Felshia S. and A. Gnanamani (D) *
The present study explores the preparation, characterization and reusability efficacy of an aminefunctionalized graphene oxide and polyphenol oxidase complex for the removal of phenol from aqueous phase. In brief, graphene oxide $(\mathrm{GO})$ is synthesized according to modified Hummer's method using graphite powder and functionalized with amine using the Bucherer's method (GO-NH purified polyphenol oxidase (PP-PPO) enzyme extracted from Solanum tuberosum is used for the preparation of the complex. The resultant $\mathrm{GO}-\mathrm{NH}_{2}-(\mathrm{PP}-\mathrm{PPO})$ complex is used for the phenol degradation studies. The samples of $\mathrm{GO}, \mathrm{GO}-\mathrm{NH}_{2}$, and $\mathrm{GO}-\mathrm{NH}_{2}-(\mathrm{PP}-\mathrm{PPO})$ complex are characterized using various instrumental techniques. Spectral UV data and FTIR and XRD diffraction patterns confirm the amine functionalization on GO. Raman spectrum, SEM micrograph and thermogravimetric (TG) analyses authenticate the linked enzyme on $\mathrm{GO}-\mathrm{NH}_{2}$. GO-NH$-(\mathrm{PP}-\mathrm{PPO})$ complex demonstrates $>90 \%$ enzyme stability at all the studied temperatures $\left(4{ }^{\circ} \mathrm{C},-20{ }^{\circ} \mathrm{C}, \mathrm{RT}\right.$ and $\left.37{ }^{\circ} \mathrm{C}\right)$. Phenol degradation studies show $>99 \%$ removal of 1000 ppm of phenol within 5 hours from the start of the experiment at the optimized $\mathrm{pH}$ of 5.0 and temperature of $30{ }^{\circ} \mathrm{C}$, as inferred from HPLC analysis. Catechol and hydroquinone compounds are identified as intermediates during the removal of phenol. Furthermore, studies on the reuse of $\mathrm{GO}-\mathrm{NH}_{2}$-(PP-PPO) complex suggest that the complex can be used effectively for the removal of phenol up to maximum 7 cycles. In conclusion, the observations made in the present study show that the complex containing amine-functionalized graphene oxide and phenoloxidase is effective for the removal of phenol with appreciable reusability.
\end{abstract}

Received 28th July 2018

Accepted 27th October 2018

DOI: $10.1039 / \mathrm{c} 8 \mathrm{ra} 06364 \mathrm{~h}$

rsc.li/rsc-advances mainly depends on specific enzymes. Enzymatic degradation and detoxification of phenol are advantageous because of its high substrate specificity, high catalytic efficiency, and mild reaction conditions. ${ }^{5}$ Among the enzymes used for wastewater treatment, polyphenol oxidases (PPO), belonging to the class oxidoreductases, catalyze the transformation of phenolic and non-phenolic aromatic compounds. ${ }^{6}$ Laccases and tyrosinases are subgroups of polyphenol oxidase, utilizes molecular oxygen to convert phenolic compounds to quinones. ${ }^{7,8}$ Both enzymes are metallic proteins with copper in their catalytic sites., ${ }^{\mathbf{9 1 0}}$ Mukherjee et al. ${ }^{11}$ comprehensively described the remediation of phenol using PPO, an enzyme found naturally in apples, bananas, grapes, mushrooms, lettuce and other fruits.

Although the use of enzymes in biotechnology and environmental applications has increased tremendously, enzymes have certain shortcomings such as lack of long-term operational stability, difficulties during recovery, reusability, sensitivity to denaturing agents and adverse sensory and toxicological effects, which hinder their use in environmental applications. ${ }^{\mathbf{1 2}}$ Immobilization of an enzyme on a solid support can circumvent these shortcomings. Immobilization increases stability, 
catalytic activity, recovery, and reusability and reduces susceptibility to microbial contamination when compared to that for free enzymes. ${ }^{\mathbf{1 3 1 4}}$ Immobilization of PPO increases the efficiency in the treatment of wastewater compared to that for free enzymes. ${ }^{15,16}$ Enzyme immobilization matrices are not restricted to calcium and copper alginate and polyamide membranes, cinnamoylated derivative-coated glass beads, chitosan beads, Celite, cellulose and Eupergit carriers, and magnetic mesoporous silica nanoparticles. ${ }^{\mathbf{1 7 - 2 1}}$

Graphene oxide (GO) may serve as an immobilization platform for enzymes via noncovalent adsorption and covalent binding. Graphene oxide (GO) exhibits a two-dimensional, $\mathrm{sp}^{2}$ hybridized, hexagonal lattice with oxygen-containing functional groups. ${ }^{22,23}$ The active surface of GO provides many reaction sites for linking the external species such as small molecules, polymers, proteins, biomacromolecules, and inorganic nanoparticles. $^{24,25}$ Zhang et al. $^{26}$ described GO as an ideal solid substrate for enzyme immobilization. However, the use of GO for immobilization depends on the surface chemistry of GO, intrinsic properties of the enzyme and the immobilization method.

Immobilization methods include adsorption, cross-linking encapsulation, entrapment and covalent binding. Apart from these methods, direct enzyme immobilization on a GO surface without any coupling reagents has been reported. ${ }^{27,28}$ However, enzymes directly linked to the surface of GO are susceptible to environmental changes, such as $\mathrm{pH}$ and temperature, and their functional groups can make immobilization unfavorable if electrostatic repulsion occurs. ${ }^{29}$ For example, the activity of chymotrypsin can be strongly inhibited by the use of as-made GO as an immobilization matrix, which necessitates the functionalization of GO to make it suitable for enzyme immobilization. ${ }^{30}$

Amine-functionalized GO might serve as an appropriate material to complex with enzymes. ${ }^{31}$ The nucleophilic nature of amine's nitrogen atom is speculated to increase the interfacial binding between GO and the material of interest. ${ }^{32}$ Amine functionalization enhances covalent bonding to polymers and biomolecules in carbon nanotubes. ${ }^{33}$ Though functionalization affects enzymatic activity in most cases, thermal stability, storage stability, and reusability of the enzyme immobilized on amine-functionalized GO sheets as a complex may improve significantly. ${ }^{34}$ Thus, the aim of the present study is to prepare a complex with partially purified polyphenol oxidase (PPO) extracted from Solanum tuberosum on amine-functionalized graphene oxide (GO) using covalent bonding and to evaluate phenol degradation efficiency as well as storage stability and reusability of the GO- $\mathrm{NH}_{2}$-(PP-PPO) complex in detail.

\section{Experimental methods}

\section{Synthesis of graphene oxide}

Graphene oxide (GO) was synthesized using modified the Hummer's method in an ice bath. ${ }^{35}$ In brief, $0.5 \mathrm{~g}$ of graphite flakes and $0.25 \mathrm{~g}$ of $\mathrm{NaNO}_{3}$ were homogenized in the presence of $11 \mathrm{~mL}$ conc. $\mathrm{H}_{2} \mathrm{SO}_{4}$ (98\%). The mixture was then stirred for $1 \mathrm{~h}$, after which $3 \mathrm{~g}$ of $\mathrm{KMnO}_{4}$ was added and stirring was continued. After $1 \mathrm{~h}, 23 \mathrm{~mL}$ of water was added, and the mixture was stirred for an hour. The mixture was then diluted by the addition of $40 \mathrm{~mL}$ of water and finally mixed with $2.5 \mathrm{~mL}$ of $\mathrm{H}_{2} \mathrm{O}_{2}$. The resulting solution was centrifuged at $7500 \mathrm{rpm}$ and $1 \mathrm{~N} \mathrm{HCl}$ was added in the ratio of $1: 10$. The resulting precipitate was washed repeatedly with distilled water until the $\mathrm{pH}$ reached 7.0; then, it was dispersed in water and used for experimental studies.

\section{Functionalization of graphene oxide}

The synthesized GO was functionalized with amine $\left(-\mathrm{NH}_{2}\right)$ groups using modified Bucherer's method. ${ }^{32}$ In brief, $0.1 \mathrm{~g}$ of GO was dispersed in $100 \mathrm{~mL}$ of water $\left(1 \mathrm{mg} \mathrm{mL}{ }^{-1}\right)$ under sonication for $30 \mathrm{~min}$ to get a uniform suspension. To $10 \mathrm{~mL}$ of the dispersed GO solution, $10 \mathrm{~mL}$ of $1 \mathrm{~N}$ ammonia and $10 \mathrm{~mL}$ of $1 \mathrm{~N}$ sodium bisulfite were added. The resulting mixture was incubated at $120^{\circ} \mathrm{C}$ for $1 \mathrm{~h}$ and centrifuged. The pellet was dried at $60{ }^{\circ} \mathrm{C}$ and used for experimental purposes.

\section{Polyphenol oxidase}

Polyphenol oxidase (PPO) was extracted from Solanum tuberosum according to the procedure described elsewhere. In brief, fresh potatoes $(100 \mathrm{~g})$ were washed and cut into pieces and homogenized with the equal volume of sodium fluoride. Ammonium sulfate (60 g) was added to the homogenized solution and the mixture was incubated overnight at $4{ }^{\circ} \mathrm{C}$. The resulting solution was centrifuged at $10000 \mathrm{rpm}$ for $15 \mathrm{~min}$ and the pellet obtained was dissolved in $10 \mathrm{~mL}$ of citrate buffer $(\mathrm{pH}$ 4.8). The buffer solution was centrifuged at $10000 \mathrm{rpm}$ for $15 \mathrm{~min}$; the collected supernatant was subjected to dialysis for $48 \mathrm{~h}$ using standard dialysis procedure, and the product was lyophilized. The lyophilized powder obtained was designated as partially purified PPO (PP-PPO) and stored at $4{ }^{\circ} \mathrm{C}$ for further use. The activity of PP-PPO was measured during each step of extraction to ensure the stability of the enzyme.

\section{Activity of PPO (polyphenol oxidase)}

The procedure for the determination of polyphenol oxidase activity is as follows. A mixture of $2.0 \mathrm{~mL} 50 \mathrm{mM}$ phosphate buffer (pH 6.5), $0.6 \mathrm{~mL}$ of distilled water and $0.2 \mathrm{~mL}$ of $50 \mathrm{mM}$ catechol was prepared. To this mixture, $0.2 \mathrm{~mL}$ of the test enzyme solution was added and the absorbance was measured at $410 \mathrm{~nm}$ using a UV-visible spectrophotometer. Distilled water was used in the place of catechol for a blank solution. All the experiments were performed in duplicates. The activity of the enzyme was calculated using the following formula:

Activity (units per mL)

$$
=\frac{\text { change in } A_{410} / \mathrm{min} \text { for test }+1000}{\mathrm{mg} \text { of enzyme in reaction }}
$$

One unit of enzyme activity is defined as the amount of enzyme that catalyzes the conversion of $1 \mathrm{mM}$ of catechol per minute. 


\section{PP-PPO and GO-NH ${ }_{2}$ complex preparation}

PP-PPO has been complexed with amine-functionalized GO to form GO-NH $\mathrm{N}_{2}$-(PP-PPO) complex. In brief, $10 \mathrm{mg}$ of lyophilized enzyme was mixed with $30 \mathrm{~mL}$ of GO-NH $\mathrm{N}_{2}$ solution $(1 \mathrm{mg} \mathrm{mL}$ concentration) and stirred for $1 \mathrm{~h}$ at $4{ }^{\circ} \mathrm{C}$. The solution was then centrifuged at $10000 \mathrm{rpm}$ for $15 \mathrm{~min}$. The amount of unbound enzyme was analyzed by evaluating the protein concentration of the supernatant using Lowry's method. ${ }^{36}$ The loading capacity of GO- $\mathrm{NH}_{2}$ was determined according to the following formula:

$$
\begin{aligned}
& \text { Loading capacity } \\
& =\frac{\text { initial amount of enzyme }- \text { amount of unbound enzyme }}{\text { initial amount of enzyme }} \\
& \times 100
\end{aligned}
$$

The samples were lyophilized and characterized using analytical techniques.

\section{Characterization studies}

The synthesized GO, GO- $\mathrm{NH}_{2}$, and GO- $\mathrm{NH}_{2}$-(PP-PPO) complex samples were characterized using various analytical and imaging techniques. The samples were suspended in aqueous medium and analyzed using a UV spectrophotometer in the range from 200 to $400 \mathrm{~nm}$ (Jasco, UV spectrophotometer 2450, Japan). The structural analysis of the samples was performed using XRD at diffraction angles $(2 \theta)$ from 5 to $80^{\circ}$ for GO, GO$\mathrm{NH}_{2}$ and GO-NH $\mathrm{H}_{2}$-PPO. $\mathrm{KBr}$ pellet technique was used to prepare samples for FTIR, and FTIR spectra were recorded for $\mathrm{GO}, \mathrm{GO}-\mathrm{NH}_{2}$ and $\mathrm{GO}-\mathrm{NH}_{2}$-(PP-PPO) samples in the range of $400-4000 \mathrm{~cm}^{-1}$. Confocal Raman system equipped with Nd:YAG laser was used for excitation of GO, GO-NH $\mathrm{N}_{2}$ and GO-NH $\mathrm{N}_{2}-(\mathrm{PP}-$ PPO). The morphology of GO, GO- $\mathrm{NH}_{2}$ and GO-NH$-(\mathrm{PP}-\mathrm{PPO})$ samples was imaged using a Phenom Pro Scanning Electron Microscope. The zeta potential of GO, GO-NH $\mathrm{N}_{2}$ and GO-NH $\mathrm{N}_{2}-(\mathrm{PP}-$ PPO) was analyzed using a zeta analyzer. The thermal stability of GO, GO-NH $\mathrm{N}_{2}$ and GO-NH $\mathrm{N}_{2}$-(PP-PPO) was analyzed using a Q-50 Thermo analyzer (TGA) in the range of $20-800{ }^{\circ} \mathrm{C}$ under a constant nitrogen flow $\left(60 \mathrm{~mL} \mathrm{~min}^{-1}\right)$.

\section{Phenol degradation studies using free PP-PPO and GO-NH${ }_{2}^{-}$ (PP-PPO) complex}

Degradation experiments were carried out using both free enzymes and the GO- $\mathrm{NH}_{2}$-(PP-PPO) complex at $\mathrm{pH} 7.0$ and $30^{\circ} \mathrm{C}$, and the degradation efficiency was calculated with respect to the incubation period. Optimization studies were carried out for $\mathrm{pH}$ in the range of 4.0-9.0 and temperature in the range of $30-80{ }^{\circ} \mathrm{C}$. Furthermore, the stability of the immobilized enzyme at various $\mathrm{pH}$ and temperatures was determined accordingly. In a typical experiment, $1000 \mathrm{ppm}$ of phenol was incubated with $30 \mathrm{mg}$ of GO-NH $\mathrm{N}_{2}$-(PP-PPO) complex for the scheduled time period of 1-5 hours. Samples were withdrawn at scheduled time intervals and subjected to HPLC analysis after centrifugation and $0.45 \mu \mathrm{m}$ membrane filtration. The analytical parameters for HPLC analysis were as follows: C-18 column, absorbance measurement at $280 \mathrm{~nm}$, flow rate of $1.0 \mathrm{~mL} \min ^{-1}$, methanol and water mixture as mobile phase (v/v $50: 50)$. The reduction in phenol concentration was calculated based on the standard graph constructed using phenol of different concentrations.

\section{Reusability}

The GO-NH $\mathrm{H}_{2}$-(PP-PPO) complex exposed to phenol was reused, and the degradation potential of the reused enzyme complex was assessed. In brief, GO-NH ${ }_{2}$-(PP-PPO) sample incubated with phenol was centrifuged after a scheduled time interval and the supernatant was removed. The pellet was then washed three times with phosphate buffer ( $\mathrm{pH}$ 6.5) and incubated with fresh phenol (1000 ppm) at an optimum temperature for $300 \mathrm{~min}$. This procedure was repeated ' $n$ ' number of times until the degradation potential decreased significantly. The relative efficiency was calculated using the following formula:

$$
\begin{aligned}
& \text { Relative efficiency }(\%) \\
& =\frac{\% \text { degradation of } 1^{\text {st }} \text { cycle }-\% \text { degradation of } n^{\text {th }} \text { cycle }}{\% \text { degradation of } 1^{\text {st }} \text { cycle }} \\
& \quad \times 100
\end{aligned}
$$

\section{Storage stability}

The storage stability of the GO- $\mathrm{NH}_{2}$-(PP-PPO) complex was assessed by incubating the samples at four different temperatures $\left(-20,4,25\right.$ and $\left.37^{\circ} \mathrm{C}\right)$ for the period of 30 days, and the phenol degradation potential was assessed at scheduled time intervals of 10 days.

\section{Results and discussion}

As described in the introduction, pollutant removal from an aqueous phase necessitates an advanced and improved method. The current research scenario for graphene suggests its potential for pollutant removal. However, graphene's potency has further been improved by altering its surface charge and energy through functionalization, which facilitates the immobilization of degradative enzymes. Compared to free enzymes, immobilized enzymes play a major role in minimizing the use of enzyme and preventing the loss of enzyme activity. Though numerous research methods are in public domain on enzyme immobilization, there is a demand for a suitable matrix for enzyme immobilization due to the requirements of possible reuse for multiple cycles. In this context, graphene oxide (GO) is considered as an appropriate matrix. However, to have an appreciable percentage of the immobilized enzyme, plain GO needs surface modifications. In recent times, aminefunctionalized graphene oxide exhibits applications in water treatment. ${ }^{37}$ Hence, in the present study, GO obtained from graphite was further functionalized with amine, and the resultant GO- $\mathrm{NH}_{2}$ was used for enzyme immobilization. Here, the enzyme chosen is polyphenol oxidase (PPO), which is known for its pollutant removal under free enzyme conditions as well as 
under immobilized conditions. Since phenol has been selected as the pollutant, PPO can be a suitable enzyme for the study. Furthermore, the source of PPO also plays a major role in designing experiments for field scale levels. Potato PPO is a chief and a suitable source based on its availability and the extraction technique. For each experimental step, necessary characterization studies of GO, GO- $\mathrm{NH}_{2}$, and GO-NH $\mathrm{N}_{2}$-(PP-PPO) complex samples were performed to authenticate the expected output and to remove phenol.

Fig. 1 illustrates UV-visible spectra of GO and GO-NH $\mathrm{H}_{2}$. The peak at $230 \mathrm{~nm}$ and a shoulder in the $300 \mathrm{~nm}$ region for GO correspond to the $\pi-\pi^{*}$ transition of aromatic $\mathrm{C}-\mathrm{C}$ bonds and the $\mathrm{n}-\pi^{*}$ transition of $\mathrm{C}=\mathrm{O}$ bonds, which are similar to the results of a previous report. ${ }^{38}$ Upon amine functionalization, a redshift from $230 \mathrm{~nm}$ to $260 \mathrm{~nm}$ is observed, and the disappearance of a shoulder at $300 \mathrm{~nm}$ suggests the replacement of phenolic oxygen atoms by $\mathrm{NH}_{2}$ functional groups on the surface



Fig. 1 UV-visible spectra of graphene oxide (GO) synthesized from graphite and amine-functionalized graphene oxide $\left(\mathrm{GO}-\mathrm{NH}_{2}\right)$.



Fig. 2 XRD patterns of graphite, GO (graphene oxide), $\mathrm{GO}-\mathrm{NH}_{2}$ (amine-functionalized graphene oxide) and $\mathrm{GO}-\mathrm{NH}_{2}$-(PP-PPO) (amine-functionalized graphene oxide partially purified polyphenol oxidase enzyme) complex.



Fig. 3 FTIR spectra of graphite, GO, GO-NH$H_{2}$ and $\mathrm{GO}-\mathrm{NH}_{2}-\mathrm{PPO}$ samples.

and the edges of GO during Bucherer's reaction. ${ }^{39}$ After complexation of PP-PPO, an insignificant shift in the absorption peak at $260 \mathrm{~nm}$ and a shoulder at 280-300 $\mathrm{nm}$ confirm the immobilization of enzyme on to the GO- $\mathrm{NH}_{2}$ matrix.

Fig. 2 illustrates the XRD patterns of graphite, GO, GO-NH and $\mathrm{GO}-\mathrm{NH}_{2}$-(PP-PPO) complex samples. The XRD pattern of graphite shows a sharp diffraction peak at $26.4^{\circ}$ with $d$-spacing of $3.35 \mathrm{~A}^{\circ}$, which represents the characteristic (002) plane peak of hexagonal graphite (JCPDS number 75-1621). After chemical exfoliation, the synthesized GO shows a sharp peak at $10.05^{\circ}$ with $d$-spacing of $8.79 \mathrm{~A}^{\circ}$. The larger $d$-spacing is ascribed to the addition of oxygen during chemical exfoliation of graphite, resulting in the formation of hydroxyl, epoxy and carbonyl functional groups. ${ }^{40}$

Upon amine functionalization, $d$-spacing further increased to $9.35 \mathrm{~A}^{\circ}$, which indicated that the surface is functionalized with $\mathrm{NH}_{2}$ groups. According to Navaee and Salimi, ${ }^{32}$ the increase in $d$-spacing helps immobilization of enzyme on GO. After immobilization of PP-PPO onto GO- $\mathrm{NH}_{2}$, the diffraction peaks of GO disappeared completely, and new peaks were observed at $16.59^{\circ}, 20.27^{\circ}, 22.42^{\circ}, 28.25^{\circ}, 29.22^{\circ}, 33.30^{\circ}, 38.75^{\circ}$, $40.00^{\circ}$ and $43.36^{\circ}$. The diffraction peak observed for graphite matched the one reported by An Gong et $a .^{41}$ and Caliman et al. ${ }^{42}$ Upon transformation to GO, the peak shifted to a lower region, which is consistent with the results reported by the abovementioned authors. Furthermore, after amine functionalization, the intensity of the peak at $2 \theta$ was reduced, indicating that amine groups were introduced between the layers of graphene oxide. According to Caliman et al. ${ }^{42}$ the introduction of amine groups into the GO structure accompanied by partial reduction of other functional groups with the interlayer spacing remaining practically unchanged corroborates our findings. The XRD pattern of the enzyme alone indicated amorphous nature despite the presence of copper in the active sites. However, when it was immobilized with amine-functionalized graphene, interestingly, peaks with lower intensity observed at higher angles $\left(30-45^{\circ}\right)$ may be due to the change in interlayer 




Fig. 4 Raman spectra of $\mathrm{GO}$ (graphene oxide), $\mathrm{GO}-\mathrm{NH}_{2}$ (aminefunctionalized graphene oxide) and $\mathrm{GO}-\mathrm{NH}_{2}$-(PP-PPO) (aminefunctionalized graphene oxide partially purified polyphenol oxidase enzyme) complex.

spacing. Moreover, the diffraction peaks observed between 30 and $40^{\circ}$ partially matched the diffraction pattern of copper and copper oxide, thus supporting the occurrence of immobilization. According to An Gong et al., ${ }^{41}$ immobilization of the enzyme naringinase increases the crystalline sizes of graphene particles, which is reflected in the intense peak at $2 \theta$ theta value.

FTIR spectra of GO, GO-NH${ }_{2}$ and GO- $\mathrm{NH}_{2}$-(PP-PPO) complex validate the functionalization of $\mathrm{NH}_{2}$ on the surface of $\mathrm{GO}$ (Fig. 3) as well the enzyme. FTIR spectra of GO showed the presence of $\mathrm{C}-\mathrm{H}$ rock $\left(860 \mathrm{~cm}^{-1}\right), \mathrm{C}-\mathrm{H}$ “oop” $\left(980 \mathrm{~cm}^{-1}\right)$, alkoxy/ alkoxide $\mathrm{C}-\mathrm{O}$ stretches $\left(1050 \mathrm{~cm}^{-1}\right)$, epoxide/ether $\mathrm{C}-\mathrm{O}$ $\left(1217 \mathrm{~cm}^{-1}\right), \mathrm{C}-\mathrm{H}$ rock $\left(1370 \mathrm{~cm}^{-1}\right)$, aromatic ring $\mathrm{C}-\mathrm{C}$ in-ring stretch $\left(1630 \mathrm{~cm}^{-1}\right)$ and $\mathrm{C}=\mathrm{O}$ stretching vibration $\left(1726 \mathrm{~cm}^{-1}\right)$. The broad peak corresponding to $\mathrm{O}-\mathrm{H}$ stretching vibration in GO $\left(3405 \mathrm{~cm}^{-1}\right)$ disappeared in the FTIR spectrum of $\mathrm{GO}-\mathrm{NH}_{2}$. Two new peaks were observed at 3030 and
$3200 \mathrm{~cm}^{-1}$, corresponding to $\mathrm{N}-\mathrm{H}$ stretching of primary/ secondary amides. The peaks at 1596 and $1650 \mathrm{~cm}^{-1}$ corresponded to the $\mathrm{N}-\mathrm{H}$ bending of primary amines, and the peak at $1030 \mathrm{~cm}^{-1}$ corresponded to $\mathrm{N}-\mathrm{H}$ wag of primary/secondary amines, indicating the presence of amine groups. The intensity of the $\mathrm{C}-\mathrm{O}$ and $\mathrm{C}=\mathrm{O}$ peaks decreased, indicating the removal of oxygen groups. Since there is no covalently bonded nitrogen on GO, the C-N stretch peak at $1160 \mathrm{~cm}^{-1}$ indicated the functionalization of amine on the surface of GO during Bucherer's reaction. ${ }^{43}$ The FTIR spectrum of GO-NH $\mathrm{H}_{2}$ (PP-PPO) complex showed the presence of a broad peak at $3130 \mathrm{~cm}^{-1}$, corresponding to the $\mathrm{N}-\mathrm{H}$ vibration of PP-PPO. The peaks at 1658 and $1571 \mathrm{~cm}^{-1}$ corresponded to primary and secondary amide groups of PP-PPO. ${ }^{44}$ The $\mathrm{C}-\mathrm{C}$ peak and $\mathrm{C}-\mathrm{H}$ peak at $1430 \mathrm{~cm}^{-1}$ and $1330 \mathrm{~cm}^{-1}$ for GO-NH$H_{2}$ and at 1405 and $1300 \mathrm{~cm}^{-1}$ for $\mathrm{GO}-\mathrm{NH}_{2}$-(PP-PPO) corresponded to stretching and rocking peaks of graphene oxide. The peak at $920 \mathrm{~cm}^{-1}$ corresponded to $\mathrm{N}-\mathrm{H}$ wag of primary/secondary amines, and the peak at $1112 \mathrm{~cm}^{-1}$ corresponded to $\mathrm{C}-\mathrm{N}$ stretch due to amine functionalization on the surface of GO. Raman spectra (Fig. 4) further supported amine functionalization and immobilization of enzymes.

The graphitic $\mathrm{G}$ band related to $\mathrm{E}_{2 \mathrm{~g}}$ vibration mode of $\mathrm{sp}^{2}$ carbon domains was observed at $\sim 1584 \mathrm{~cm}^{-1}$ for GO, $1594 \mathrm{~cm}^{-1}$ for GO-NH${ }_{2}$ and $1599 \mathrm{~cm}^{-1}$ for GO-NH${ }_{2}$-(PP-PPO), which explains the degree of graphitization. The intensity of $\mathrm{D}$ band explains the structural defects in graphitic structure and partially disordered structures of $\mathrm{sp}^{2}$ domains. The $\mathrm{D}$ band observed at $1340 \mathrm{~cm}^{-1}$ shifted to $1354 \mathrm{~cm}^{-1}$ for $\mathrm{GO}-\mathrm{NH}_{2}$ and GO-NH $\mathrm{NH}_{2}$-(PP-PPO) complex. The defects introduced by oxidation of graphite are clear from the $I_{\mathrm{D}} / I_{\mathrm{G}}$ ratio of 1.28 for $\mathrm{GO}$, indicating the change in hybridization from $\mathrm{sp}^{3}$ to $\mathrm{sp}^{2} .{ }^{45}$ Upon functionalization of amine groups, the $I_{\mathrm{D}} / I_{\mathrm{G}}$ ratio increased from 1.28 to 1.31 . The $I_{\mathrm{D}} / I_{\mathrm{G}}$ ratio is a measure of disorderliness and describes the relative disorder due to structural imperfections. Enhanced defects due to $\mathrm{sp}^{3}$ hybridized $\mathrm{C}$ atoms might be responsible for the increase in $I_{\mathrm{D}} / I_{\mathrm{G}}$ ratio after



Fig. 5 Scanning electron microscopy images of GO (graphene oxide) and GO- $\mathrm{NH}_{2}$-(PP-PPO) (amine-functionalized graphene oxide partially purified polyphenol oxidase enzyme) complex. 
Table 1 Zeta potential analysis of $\mathrm{GO}, \mathrm{GO}-\mathrm{NH}_{2}$ and $\mathrm{GO}-\mathrm{NH}_{2}-(\mathrm{PP}-$ PPO) complex

\begin{tabular}{|c|c|c|c|}
\hline Sample & $\begin{array}{l}\text { Zeta potential } \\
(\mathrm{mV})\end{array}$ & $\begin{array}{l}\text { Zeta deviation } \\
(\mathrm{mV})\end{array}$ & $\begin{array}{l}\text { Conductivity } \\
\left(\mathrm{mS} \mathrm{cm}^{-1}\right)\end{array}$ \\
\hline GO & -0.595 & 183 & 0.0479 \\
\hline GO-NH ${ }_{2}$ & -5.50 & 15.2 & 0.174 \\
\hline GO-NH ${ }_{2}-(\mathrm{PP}-\mathrm{PPO})$ & -20 & 8.51 & 0.0394 \\
\hline
\end{tabular}

functionalization. The $I_{\mathrm{D}} / I_{\mathrm{G}}$ ratio decreased substantially upon enzyme immobilization. The possible reason for this observation might be the inherent carbon vibration of the enzyme increasing the intensity of $\mathrm{G}$ band. The new peaks arising around $1100 \mathrm{~cm}^{-1}$ correspond to those of the PP-PPO enzyme.

Fig. 5a presents the scanning electron microscopy images of $\mathrm{GO}$ and GO-NH $\mathrm{H}_{2}$-PPO. The SEM image of GO indicates sheet-like morphology. The sheet-like morphology of GO indicates the chemical exfoliation of graphite, and the addition of oxygen functional groups in between the layers and the flower-like mass may represent the immobilized enzyme.

Zeta potential indicates the stability of colloidal solutions. ${ }^{46}$ The magnitude of zeta potential designates the degree of electrostatic repulsion in similarly charged surfaces of a material dispersed in a solvent. GO- $\mathrm{NH}_{2}$ exhibited a zeta potential $\sim 9.25$ times higher than that of GO, whereas $\mathrm{GO}-\mathrm{NH}_{2}-(\mathrm{PP}-\mathrm{PPO})$ exhibited $\sim 5.45$ times higher zeta potential than $\mathrm{GO}-\mathrm{NH}_{2}$ (Table 1). The results indicated that $\mathrm{GO}-\mathrm{NH}_{2}$ had greater stability of colloidal dispersion than GO, and when immobilized with PP-PPO, the stability increased further. The high colloidal stability of PP-PPO-immobilized GO- $\mathrm{NH}_{2}$ is consistent with degradation as the experiments are mostly carried out in liquid media.

Fig. 6 presents the thermogravimetric analysis (TGA) of the samples GO and GO-NH $\mathrm{N}_{2}$. GO was thermally unstable and upon heating, weight loss was observed. The initial weight loss of $22 \%$ at $169{ }^{\circ} \mathrm{C}$ was ascribed to the removal of trapped water molecules and epoxy oxygen functional groups. Major weight

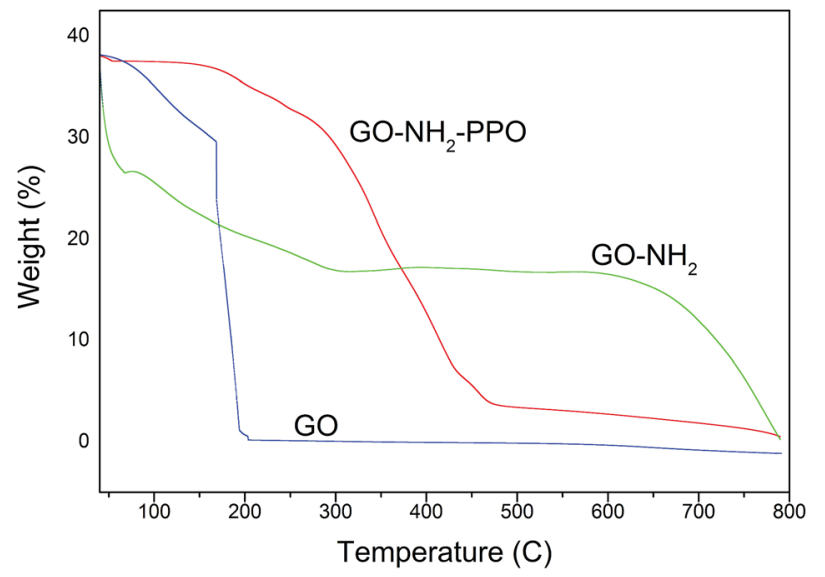

Fig. 6 Thermogravimetric analysis (TGA) of GO (graphene oxide), GO$\mathrm{NH}_{2}$ (amine-functionalized graphene oxide), and $\mathrm{GO}-\mathrm{NH}_{2}-(\mathrm{PP}-\mathrm{PPO})$ (amine-functionalized graphene oxide complex). loss of $74 \%$ observed at $200{ }^{\circ} \mathrm{C}$ may be due to the removal of labile oxygen functional groups by pyrolysis, yielding $\mathrm{CO}, \mathrm{CO}_{2}$, and steam. ${ }^{47,48}$ Huge weight loss due to the oxygen atoms indicates high degree of oxidation during chemical exfoliation of graphite. Functionalization of GO by amine groups enhances the thermal stability of $\mathrm{GO}$. Below $100{ }^{\circ} \mathrm{C}, \mathrm{GO}-\mathrm{NH}_{2}$ shows nearly zero weight loss. ${ }^{49}$ Weight loss of $87.5 \%$ occurs gradually from 100 to $475{ }^{\circ} \mathrm{C}$. This observation also indicates that oxygen functional groups have been replaced by amine functional groups during Bucherer's reaction. A weight loss of $23 \%$ observed below $100{ }^{\circ} \mathrm{C}$ in PP-PPO-immobilized GO-NH ${ }_{2}$ might be due to the moisture content of the enzyme. The TGA curve of GO-NH ${ }_{2}-(\mathrm{PP}-\mathrm{PPO})$ shows $50 \%$ weight loss within $400{ }^{\circ} \mathrm{C}$, which might be due to the loss of functionalized amine groups and organic residues of the enzyme.

At $750{ }^{\circ} \mathrm{C}, 67 \%$ weight loss was observed. The weight loss in GO-NH $\mathrm{N}_{2}$-(PP-PPO) was lower than those of $\mathrm{GO}$ and $\mathrm{GO}-\mathrm{NH}_{2}$, where $99.1 \%$ and $93.1 \%$ weight losses occurred at $750{ }^{\circ} \mathrm{C}$. The possible reason might be the presence of copper in catalytic sites in PPO, which is not lost on heating to $750{ }^{\circ} \mathrm{C}$ and adds to the weight of the pan in TGA.

\section{Phenol degradation experiments}

The activity of PPO in GO-NH ${ }_{2}-(\mathrm{PP}-\mathrm{PPO})$ complex was evaluated and compared with that of the free enzyme to determine the loading capacity of PP-PPO on to GO-NH ciency of PP-PPO on to GO- $\mathrm{NH}_{2}$ was calculated to be $81 \%$. The experiments with GO and GO- $\mathrm{NH}_{2}$ on phenol removal demonstrated no changes in phenol concentration and hence were not included in the experimental studies. Furthermore, the initial trial experiments using GO- $\mathrm{NH}_{2}$-(PP-PPO) complex with $500 \mathrm{ppm}$ phenol displayed complete removal within $3 \mathrm{~h}$, whereas for the same concentration of free enzyme, phenol could not be removed completely even after $24 \mathrm{~h}$ incubation. This result has been ascribed to the inhibition of free enzyme activity due to the intermediates released during degradation. Zhang et $a l^{43}$ reported higher degradation efficiency for immobilized enzymes compared to that of free enzymes and stated that immobilized enzymes are more suitable for degradation experiments. The possible reason might be the resistance of the immobilized enzyme towards higher concentration of a pollutant compared to that of free enzymes. The immobilization matrix GO selectively improves the catalytic activity of some enzymes and does not affect the activity of others..$^{50}$

Fig. 7a depicts the enzyme activity profile of the immobilized enzyme studied at different $\mathrm{pH}$ conditions, and it revealed that the maximum activity $\left(148 \mathrm{U} \mathrm{mL}^{-1}\right)$ was observed at $\mathrm{pH}$ 5.0. With reference to temperature, the immobilized enzyme displayed maximum activity at $30{ }^{\circ} \mathrm{C}$ (Fig. $7 \mathrm{~b}$ ). Similar to these observations, phenol degradation efficiency of the complex at varied $\mathrm{pH}$ conditions showed $46-61 \%$ degradation at $\mathrm{pH}$ of $4.0-$ 5.0 and at the temperature of $30^{\circ} \mathrm{C}$. With respect to stability of the enzyme, the immobilized enzyme was stable at wide $\mathrm{pH}$ (4.0-7.0) and temperature $\left(30-45{ }^{\circ} \mathrm{C}\right)$ conditions, whereas PPO isolated from litchi pericarp showed inactivation at higher $\mathrm{pH}$ and temperature. ${ }^{51}$ 

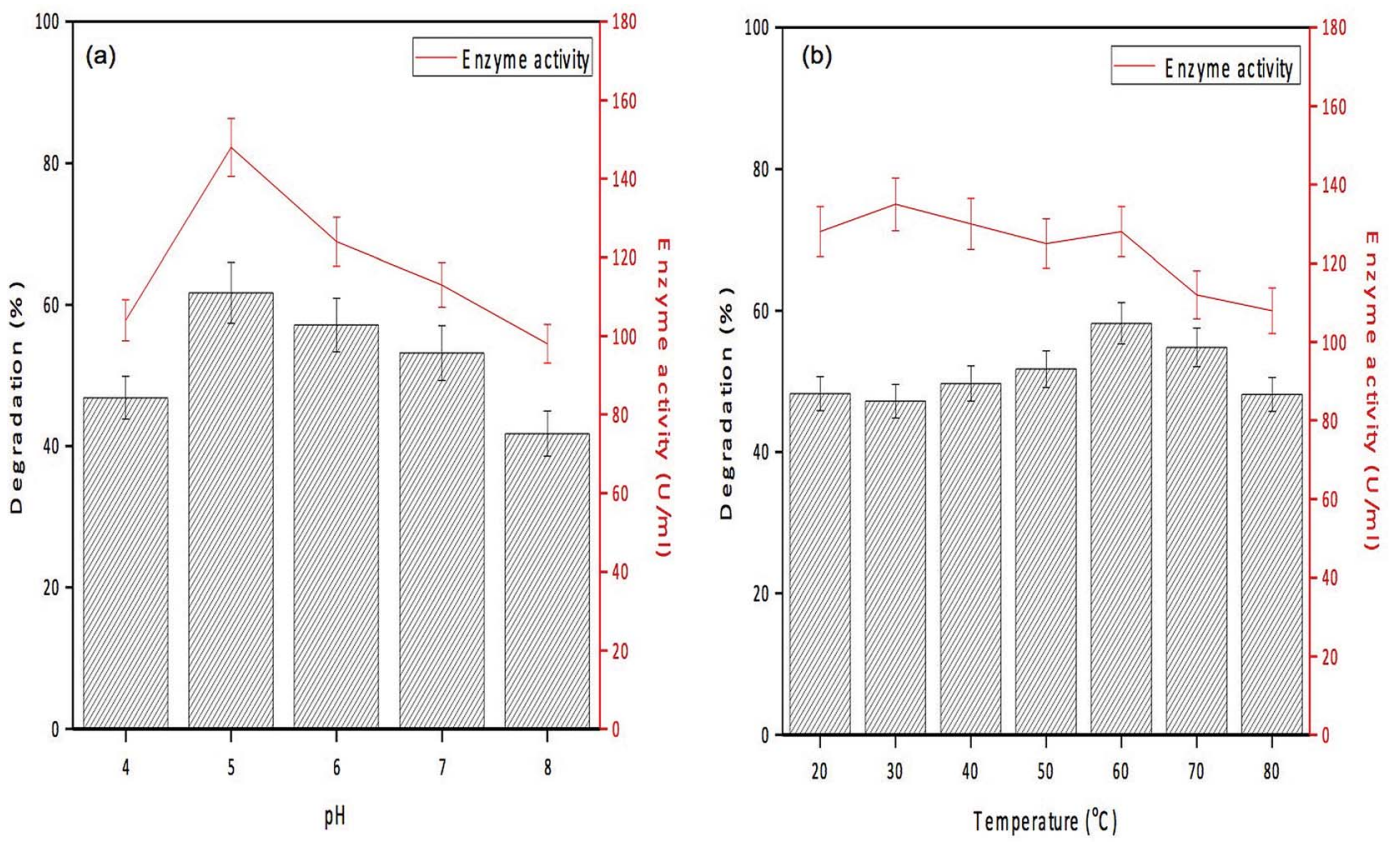

Fig. 7 Degradation efficiency and enzyme activity profile of $\mathrm{GO}-\mathrm{NH}_{2}$-(PP-PPO) (amine-functionalized graphene oxide complex) at (a) different $\mathrm{pHs}$ and (b) different temperatures.

Degradation experiments were carried out for $1000 \mathrm{ppm}$ phenol at the optimum conditions of $\mathrm{pH}(5.0)$ and temperature $\left(30^{\circ} \mathrm{C}\right)$, and samples were withdrawn every $15 \mathrm{~min}$ up to $1 \mathrm{~h}$ and at every hour thereafter. Fig. 8 presents the HPLC graph of degradation of phenol using GO-NH${ }_{2}$ (PP-PPO) along with the standard at $1000 \mathrm{ppm}$ concentration. It has been observed that over time, the intensity of the peak observed at RT 9.0 corresponding to phenol decreases, which indicates the degradation of phenol. The degradation efficiency increased with time from $40 \%$ in $15 \mathrm{~min}$ to $99.5 \%$ in $300 \mathrm{~min}$. After $5 \mathrm{~h}$ of incubation with GO-NH$-(\mathrm{PP}-\mathrm{PPO})$ complex, complete transformation was observed. Furthermore, HPLC results showed additional peaks at RT of 5.1 and RT of 1.4, corresponding to the intermediate products formed during the degradation process (Fig. 8). On comparing the intermediate peaks, RT of 5.1 corresponds to catechol and RT of 1.4 corresponds to hydroquinone.

\section{Reusability and storage stability}

The reusability of GO- $\mathrm{NH}_{2}$-(PP-PPO) complex for phenol degradation was analyzed by measuring the degradation efficiency of the complex after each cycle. After each experimental cycle, the samples were analyzed using HPLC to assess degradation. The reusability studies with the complex revealed that the complex retained $>98 \%$ of its activity up to 5 cycles, $<85 \%$ after 7 cycles and $<50 \%$ after 9 cycles of reuse (Fig. 9a). The results indicated that the complex was reusable before losing its degradation efficiency and activity. The loss of activity might be due to repeated washing. ${ }^{29}$

With respect to storage stability, the activity of free enzyme was completely lost within 3 days at all the temperatures studied. However, immobilized enzyme retained more than
$90 \%$ of its activity until 15 days of incubation at temperatures of $-20{ }^{\circ} \mathrm{C}$ and $4{ }^{\circ} \mathrm{C}$. At room temperature and $37{ }^{\circ} \mathrm{C}$, only $85 \%$ and $80 \%$ of activities were retained up to 10 days, respectively, and loss in the activity was observed after 10 days (Fig. 9b).

Table 2 depicts the comparative efficacy of phenol degradation studies using immobilized enzymes in different matrices. Among all the matrices, amine-functionalized graphene displayed appreciable degradation efficiency with increase in reusability cycle as well as stability of the immobilized enzymes. The complex prepared in the present study removes phenol at a much faster rate and can be effectively used for transformation of phenolic compounds at industrial scale.

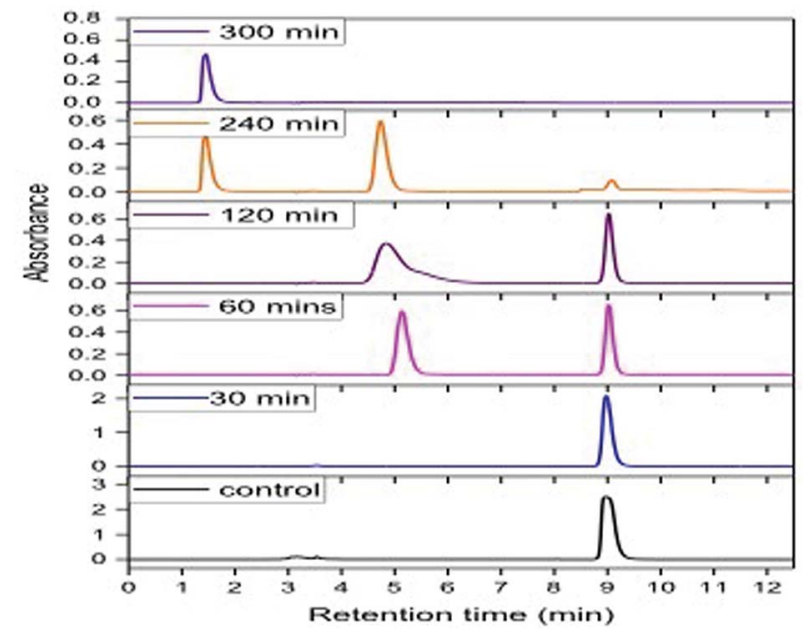

Fig. $8 \mathrm{HPLC}$ chromatogram of phenol at $1000 \mathrm{ppm}$ concentration at different time intervals of incubation with $\mathrm{GO}-\mathrm{NH}_{2}$-(PP-PPO) (aminefunctionalized graphene oxide complex). 
(a)

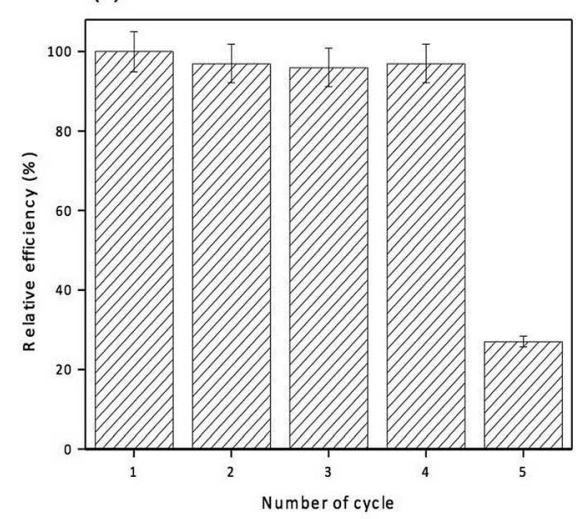

(b)

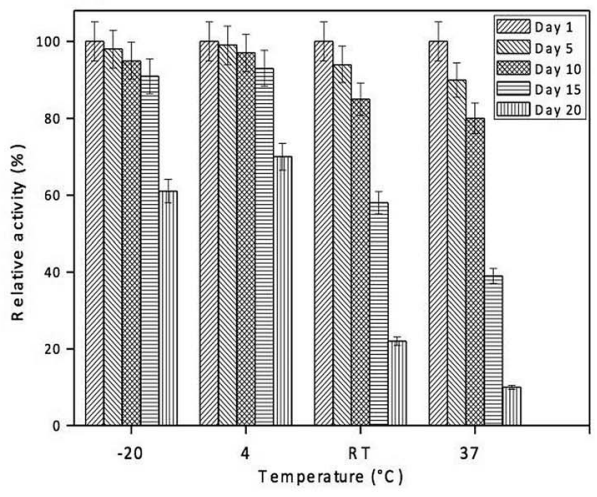

Fig. 9 (a) Reusability and degradation efficiency of $\mathrm{GO}-\mathrm{NH}_{2}$-(PP-PPO) (amine-functionalized graphene oxide partially purified polyphenol oxidase enzyme) complex with reference to phenol degradation. (b) Storage stability of immobilized enzyme (GO-NH $\mathrm{H}_{2}-(\mathrm{PP}-\mathrm{PPO})$ ) (aminefunctionalized graphene oxide partially purified polyphenol oxidase enzyme) complex with reference to four different temperatures ( $-20,4$, room temperature (RT) and $37^{\circ} \mathrm{C}$ ) and the relative activity.

Table 2 Comparison of degradation efficiency and reusability of immobilized enzymes for phenolic compounds

\begin{tabular}{|c|c|c|c|c|c|}
\hline Compound & Enzyme & Matrix & No. of cycles & $\begin{array}{l}\text { Time taken } \\
\text { (h) }\end{array}$ & $\begin{array}{l}\text { Concentration } \\
\text { (ppm) }\end{array}$ \\
\hline Phenol $^{21}$ & Laccase & Silica nanoparticles & 10 & 3 & $50-100$ \\
\hline Phenol $^{53}$ & HRP & GO & 4 & 3 & 90 \\
\hline Chlorophenol $^{54}$ & PPO & $\mathrm{Fe}_{3} \mathrm{O}_{4} / \mathrm{GO}$ & 4 & 3.5 & 4.7 \\
\hline Phenol $^{55}$ & HRP & Carbon nanospheres & 5 & 1.25 & 161.68 \\
\hline
\end{tabular}

\section{Conclusion}

The present study explores whether amine-functionalized graphene oxide (GO) and phenoloxidase complex can perform the removal of phenol from the aqueous phase. Also, the reusability of the complex for the maximum number of cycles was tested since it can appreciably reduce the cost involved in the direct use of enzymes for environmental cleanup. The first step involves amine functionalization of GO, followed by preparation of the complex using polyphenol oxidase extracted from Solanum tuberosum. The enzyme was partially purified before forming a complex with amine-functionalized GO. Various analytical techniques such as UV, XRD, FTIR, Raman, zeta potential and TGA were performed to authenticate the complex formation. The surface morphology of GO analyzed using SEM revealed sheet-like morphology before complexation with PPO, whereas the complex showed aggregates, which could be due to the presence of enzyme. The results on optimization studies revealed that $\mathrm{pH}$ of 5.0 and temperature of $30{ }^{\circ} \mathrm{C}$ are the optimum conditions for degradation of phenol, where the enzyme exhibits higher activity compared to enzymes studied in other conditions. Under optimum conditions, the GO-NH${ }_{2}$-(PPPPO) complex could completely degrade $1000 \mathrm{ppm}$ of phenol, as inferred from HPLC analysis with catechol and hydroquinone as intermediates. The GO- $\mathrm{NH}_{2}-(\mathrm{PP}-\mathrm{PPO})$ complex retained its $>98 \%$ activity up to 5 cycles, $<80 \%$ after 7 cycles and $<50 \%$ after
9 cycles of reuse. With respect to storage stability, $>90 \%$ activity was retained after 15 days of storage at $-20{ }^{\circ} \mathrm{C}$ and $4{ }^{\circ} \mathrm{C}$, and $>90 \%$ activity was retained only up to 10 days when stored at room temperature and $37^{\circ} \mathrm{C}$.

\section{Funding source}

No external funds were used for the study.

\section{Conflicts of interest}

There are no conflicts to declare.

\section{Acknowledgements}

First author Mr Pravin acknowledges CSIR-CLRI for the permission granted to carry out his MS (By) research. Author Chris Felshia acknowledges CSIR, New Delhi for the fellowship awarded in the form of CSIR-SRF and University of Madras for her $\mathrm{PhD}$ degree.

\section{References}

1 J. Sikkema, J. A. de Bont and B. Poolman, Microbiol. Rev., 1995, 59, 201-222. 
2 P. M. Fedorak and S. E. Hrudey, in Water Pollution Research and Control Brighton, 1988, pp. 67-76.

3 C. Mahugo Santana, Z. Sosa Ferrera, M. Esther Torres Padrón and J. Juan Santana Rodríguez, Molecules, 2009, 14, 298-320.

4 S. C. Felshia, N. A. Karthick, R. Thilagam, A. Chandralekha, K. Raghavarao and A. Gnanamani, J. Environ. Manage., 2017, 197, 373-383.

5 J. Ai, W. Zhang, G. Liao, H. Xia and D. Wang, RSC Adv., 2016, 6, 38117-38123.

6 N. Duran and E. Esposito, Appl. Catal., B, 2000, 28, 83-99.

7 C. Queiroz, M. L. Mendes Lopes, E. Fialho and V. L. ValenteMesquita, Food Rev. Int., 2008, 24, 361-375.

8 Ş. Şimşek and A. Yemenicioğlu, Process Biochem., 2007, 42, 943-950.

9 C. A. Ramsden and P. A. Riley, Bioorg. Med. Chem., 2014, 22, 2388-2395.

10 S. Riva, Trends Biotechnol., 2006, 24, 219-226.

11 S. Mukherjee, B. Basak, B. Bhunia, A. Dey and B. Mondal, Rev. Environ. Sci. Bio/Technol., 2013, 12, 61-73.

12 L. Cao, L. van Langen and R. A. Sheldon, Curr. Opin. Biotechnol., 2003, 14, 387-394.

13 U. Hanefeld, L. Gardossi and E. Magner, Chem. Soc. Rev., 2009, 38, 453-468.

14 R. A. Sheldon and S. van Pelt, Chem. Soc. Rev., 2013, 42, 6223-6235.

15 G. Bayramoğlu and M. Y. Arıca, J. Hazard. Mater., 2008, 156, 148-155.

16 E. Kameda, M. Langone and M. Coelho, Environ. Technol., 2006, 27, 1209-1215.

17 P. Peralta-Zamora, C. M. Pereira, E. R. Tiburtius, S. G. Moraes, M. A. Rosa, R. C. Minussi and N. Durán, Appl. Catal., B, 2003, 42, 131-144.

18 A. A. Khan and Q. Husain, Bioresour. Technol., 2007, 98, 1012-1019.

19 J. Shao, H. Ge and Y. Yang, Biotechnol. Lett., 2007, 29, 901905.

20 N. Lončar, N. Božić, I. Anđelković, A. Milovanović, B. Dojnov, M. Vujčić, G. Roglić and Z. Vujčić, J. Serb. Chem. Soc., 2011, 76, 513-522.

21 F. Wang, Y. Hu, C. Guo, W. Huang and C. Z. Liu, Bioresour. Technol., 2012, 110, 120-124.

22 M. I. Katsnelson, Mater. Today, 2007, 10, 20-27.

23 A. Bianco, H.-M. Cheng, T. Enoki, Y. Gogotsi, R. H. Hurt, N. Koratkar, T. Kyotani, M. Monthioux, C. R. Park and J. M. Tascon, Carbon, 2013, 1-6.

24 G. B. Sukhorukov, A. L. Rogach, B. Zebli, T. Liedl, A. G. Skirtach, K. Köhler, A. A. Antipov, N. Gaponik, A. S. Susha and M. Winterhalter, Small, 2005, 1, 194-200.

25 C. Xu, X. Wang and J. Zhu, J. Phys. Chem. C, 2008, 112, 19841-19845.

26 Y. Zhang, C. Wu, S. Guo and J. Zhang, Nanotechnol. Rev., 2013, 2, 27-45.

27 Y. Liu, D. Yu, C. Zeng, Z. Miao and L. Dai, Langmuir, 2010, 26, 6158-6160.

28 D. Y. Lee, Z. Khatun, J. H. Lee, Y. K. Lee and I. In, Biomacromolecules, 2011, 12, 336-341.
29 F. Zhang, B. Zheng, J. Zhang, X. Huang, H. Liu, S. Guo and J. Zhang, J. Phys. Chem. C, 2010, 114, 8469-8473.

30 M. De, S. S. Chou and V. P. Dravid, J. Am. Chem. Soc., 2011, 133, 17524-17527.

31 F. Wang, J. J.-H. Haftka, T. L. Sinnige, J. L. Hermens and W. Chen, Environ. Pollut., 2014, 186, 226-233.

32 A. Navaee and A. Salimi, RSC Adv., 2015, 5, 59874-59880.

33 T. Ramanathan, F. Fisher, R. Ruoff and L. Brinson, Chem. Mater., 2005, 17, 1290-1295.

34 I. V. Pavlidis, T. Vorhaben, T. Tsoufis, P. Rudolf, U. T. Bornscheuer, D. Gournis and H. Stamatis, Bioresour. Technol., 2012, 115, 164-171.

35 W. Humers and R. Offeman, J. Am. Chem. Soc., 1958, 80, 1339.

36 O. H. Lowry, J. Biol. Chem., 1951, 193, 265-275.

37 K. Yang, L. Feng, X. Shi and Z. Liu, Chem. Soc. Rev., 2013, 42, 530-547.

38 L. Coche-Guerente, P. Labbe and V. Mengeaud, Anal. Chem., 2001, 73, 3206-3218.

39 Y. Fu, L. Liu and J. Zhang, ACS Appl. Mater. Interfaces, 2014, 6, 14069-14075.

40 S. Wu, T. Shi and L. Zhang, High Perform. Polym., 2016, 28, 453-465.

41 A. Gong, C.-T. Zhu, Y. Xu, F.-Q. Wang, D. K. Tsabing, F.-A. Wu and J. Wang, Sci. Rep., 2017, 7, 4309.

42 C. C. Caliman, A. F. Mesquita, D. F. Cipriano, J. C. C. Freitas, A. A. C. Cotta, W. A. A. Macedo and A. O. Porto, $R S C A d v$, 2018, 8, 6136-6145.

43 F. Zhang, W. Zhang, L. Zhao and H. Liu, Desalin. Water Treat., 2016, 57, 24406-24416.

44 C. Shi, Y. Dai, Q. Liu, Y. Xie and X. Xu, J. Mol. Struct., 2003, 644, 139-144.

45 D. Kostiuk, M. Bodik, P. Siffalovic, M. Jergel, Y. Halahovets, M. Hodas, M. Pelletta, M. Pelach, M. Hulman and Z. Spitalsky, J. Raman Spectrosc., 2016, 47, 391-394.

46 R. J. Hunter, Colloids Surf., A, 1998, 141, 37-66.

47 A. Lerf, H. He, M. Forster and J. Klinowski, J. Phys. Chem. B, 1998, 102, 4477-4482.

48 S. Stankovich, D. A. Dikin, R. D. Piner, K. A. Kohlhaas, A. Kleinhammes, Y. Jia, Y. Wu, S. T. Nguyen and R. S. Ruoff, Carbon, 2007, 45, 1558-1565.

49 A. Shanmugharaj, J. Yoon, W. Yang and S. H. Ryu, J. Colloid Interface Sci., 2013, 401, 148-154.

50 L. Jin, K. Yang, K. Yao, S. Zhang, H. Tao, S.-T. Lee, Z. Liu and R. Peng, ACS Nano, 2012, 6, 4864-4875.

51 G. P. Mizobutsi, F. L. Finger, R. A. Ribeiro, R. Puschmann, L. L. d. M. Neves and W. F. d. Mota, Sci. Agric., 2010, 67, 213-217.

52 G. B. Seetharam and B. A. Saville, Water Res., 2003, 37, 436440.

53 S. C. Chang, K. Rawson and C. J. McNeil, Biosens. Bioelectron., 2002, 17, 1015-1023.

54 Q. Chang, G. Jiang, H. Tang, N. Li, J. Huang and L. Wu, Chin. J. Catal., 2015, 36, 961-968.

55 Y. M. Lu, Q. Y. Yang, L. M. Wang, M. Z. Zhang, W. Q. Guo, Z. N. Cai, D. D. Wang, W. W. Yang and Y. Chen, Clean: Soil, Air, Water, 2017, 45, 1600077. 